\title{
A NOTE ON INEQUALITIES DUE TO CLAUSING AND LEVIN-STEČKIN
}

\author{
PETER R. MERCER
}

Abstract. A single argument yields inequalities due to Clausing and Levin-Stečkin.

Mathematics subject classification (2010): 26D15.

Keywords and phrases: convexity; Levin-Steckin.

\section{REFERENCES}

[1] A. Clausing Disconjugacy and Integral Inequalities, Trans. Amer. Math. Soc. 260 (1980), 293-307.

[2] V. I. Levin And S. B. StečKIn, Inequalities, Amer. Math. Soc. Transl. (2) 14 (1960), 1-29.

[3] J. Lukeš, J. Malý, I. Netuka And J. SPuRnÝ, Integral Representation Theory, deGruyter 2010.

[4] J. E. PeČarić, F. Proschan And Y. C. Tong, Convex Functions, Partial Orderings and Statistical Applications, Academic Press, New York, 1992.

[5] J. E. PEČARIĆ AND A. UR REHMAN, Cauchy means introduced by an inequality of Levin and Stečkin, East J. on Approximations, 15 (2009), 429-438. 